УДК 339.5:633.1(477)

Савош Л.В., к.е.н., доцент, Larysa Savosh, Candidate of Economic Sciences, Associate Professor https://orcid.org/0000-0003-0831-201X

Ковальська Л.Л., д.е.н., професор

Lyubov Kovalska, Doctor of Economic Sciences, Professor http://orcid.org/0000-0003-2924-9857

Баула О.В., к.е.н., доцент

Olena Baula, Candidate of Economic Sciences, Associate Professor https://orcid.org/0000-0003-2609-0211

\title{
АНАЛІЗ ПОЗИЦЙ УКРАЇНИ НА СВІТОВОМУ РИНКУ ЗЕРНА
}

\author{
Луияький національний технічний університет, Луияьк
}

В статті проведено дослідження стану позицій України на світовому ринку зерна за останні 5 років. Одночасно відмітимо, що Україна має одні з найбільш сприятливих умов у світі для вирощування зернових культур. Значні площі земельних ресурсів високої якості та сприятливі кліматичні умови визначають визнаний високий експортний потенціал сільського господарства для міжнародної торгівлі. Саме в цих аспектах відображається актуальність обраної теми наукових досліджень даної публікації.

Проведені дослідження підтверджують, що зерновий ринок України глибоко інтегрований у світовий аграрний ринок. Частка виробництва зернових України у загальному світовому виробництві зернових за 2015-2019 рр. коливалась в межах 3\%, а сама Україна входить в десятку країн-лідерів виробників зернових культур. Що стосується експорту зернових культур, то його частка за 2015-2019 рр. коливалась від 10,7\% до 13,6\%. У 2019 році Україна увійшла до ТОП-5 експортерів зернових культур.

Позиції України на світовому ринку зерна зростатимуть і в майбутньому, оскільки зростатиме попит і країна має значний нереалізований виробничий потенціал, який визначається такими двома чинниками, як майже вдвічі нижчі показники врожайності основних зернових культур, ніж у інших країнлідерів та найвищі показники у світі родючості українських земель. Основними перспективними напрямами підвищення конкурентоспроможності вітчизняного зерна на світовому ринку є ріст обсягів виробництва зерна та зростання його урожайності за рахунок залучення іноземних інвестицій для оновлення матеріально-технічної бази; покращення якості зерна і поглиблення його переробки; оптимізація землеволодіння та землекористування; подальший розвиток ринкової інфраструктури; раціональне державне регулювання, подолання корупції на зерновому ринку.

Ключові слова: світовий ринок зерна, вітчизнянй ринок зерна, сільське господарство, зернові культури, посівна площа, експорт зерна.

\section{ANALYSIS OF UKRAINE'S POSITION ON THE WORLD GRAIN MARKET}

\author{
Lutsk National Technical University, Lutsk
}

This article examines Ukraine's position in the world grain market over the past 5 years. It is important to mention that Ukraine benefits from the most favorable conditions in the world for growing grain crops. The high potential of export in agriculture for international trade is determined by significant areas of high-quality lands and favorable climatic conditions. These drivers contribute to the relevance of the research topic of the current publication.

Studies indicate that the grain market of Ukraine is profoundly integrated into the world`s agricultural market. The share of grain production of Ukraine is around 3\% in the total world grain production during 20152019. Besides, Ukraine is listed in the top ten countries of grain crop production. Regarding the export of grain crops, Ukraine`s share ranged from $10,7 \%$ to $13,6 \%$ during $2015-2019$. Ukraine took a place among the top 5 export countries of grain crops in 2019.

The importance of Ukraine in the world grain market is deemed to be developing in the future due to the growing demand. In addition, the country has significant production potential, which was not yet implemented. This potential is determined by two key factors such as almost two times lower harvests of major grains comparing to other leading countries, and the highest fertility rates of the land worldwide. The principal areas for increasing the competitiveness of Ukraine in the world grain market are the growth of grain production as well as an increase in the harvest. The last objective can be reached by attracting foreign investment to upgrade the material and technical base. Moreover, such factors as the improvement of the quality of grain along with the deepening process, optimization of land tenure and land use, further development of market infrastructure, rational state regulation, 
and overcoming corruption of the grain market could greatly contribute to the growth of the competitiveness of Ukraine in the world grain market.

Key words: world grain market, domestic grain market, agriculture, grain crops, sown area, grain export.

Постановка проблеми у загальному вигляді i ï зв'язок 3 важливими науковими та практичними завданнями. Світовий ринок зерна є одним із найбільш важливих стратегічних елементів світового ринку аграрної продукції. Це зумовлено важливим значенням зерна, як стратегічного продукту, який забезпечує національну продовольчу безпеку та формує експортний потенціал галузі сільськогосподарського виробництва; як сировини для зернопереробної промисловості і основного корму для тварин; як доступного енергоносія шляхом переробки зерна на біоетанол тощо.

Суть постановки проблеми полягає в тому, щоб визначити позиції України як виробника та експортера на світовому ринку зернових культур та окреслити проблеми та напрями їх усунення для даної складової ринку сільськогосподарської продукції. Розв'язання окреслених завдань передбачено розглянути у наступних складових наукової публікації.

Аналіз останніх досліджень, у яких започатковано вирішення проблеми. Дослідження розвитку світового та вітчизняного зернового ринку проводили багато видатних науковців та практиків, зокрема: А.І. Алтухов [1], В.К. Збарський [8], А.М. Карпенко [9], І.Г. Кириленко [10], С.В. Майстро [11], П.Т. Саблук [12], О.М. Саковська [13], Л.М. Худолій [14], О.Г. Шпикуляк [12], О.М. Шпичак [15] та інші.

Незважаючи на значні досягнення вчених у дослідженні світового і вітчизняного ринку зерна, залишаються багато питань, які потребують вирішення. В умовах динамічних аграрних перетворень загострюється увага на чинниках, які формують виробничий та експортний потенціал вітчизняного ринку. Крім того питання функціонування сільськогосподарських підприємств на світовому ринку зерна, проблема пошуку способів зростання їх ефективності та експортної активності залишаються ще недостатньо розкритими, оскільки можливість вільного виходу на світовий ринок зерна вітчизняні виробники отримали відносно недавно: менше трьох десятиліть тому.

Саме тому, можна із впевненістю констатувати, що у питанні функціонуванні вітчизняних зерновиробників та зростання їх конкурентоспроможності на світовому ринку зерна, є значна кількість аспектів, які потребують наукового обгрунтування. Ми звернемо увагу на деякі із них, а саме: на позиції України та світовому ринку зерна, проблеми та перспективи їх покращення.

Цілі статті полягають у дослідженні світового ринку зерна та позицій України на ньому. Для реалізації цілей окреслено конкретні завдання, вирішення яких дозволить оцінити сучасний стан світового ринку зерна, а також особливості, проблеми і потенціал вітчизняного зернового ринку. Вирішення цих завдань сприятиме зростанню виробництва та експорту вітчизняних зернових культур та зміцненню позицій України на світовому ринку зерна, що в кінцевому підсумку буде зміцнювати національну продовольчу безпеку та експортний потенціал країни.

\section{Виклад основного матеріалу дослідження 3 повним обгрунтуванням отриманих наукових результатів.}

За визначенням Алтухова А.І. «ринок зерна - це складне явище, яке містить економічні, фінансові і соціальні складові» [1, С.7-13]. Україна потужно представлена на світовому ринку зерна, оскільки має одні з найбільш сприятливих умов для вирощування зернових культур у світі. «Зерно є основою для виробництва продуктів харчування, сировиною для багатьох промислових галузей, використовується як кормова база для тварин та є невід’ємною складовоюпродовольчої безпеки країни», - так стверджують Ірина Грузінська, Альона Смагіна, Мануел Айрапетов, Віталій Жигадло у Зеленій книзі «Регулювання ринку зерна» [2, с.7].

Для української економіки сільське господарство історично є найважливішою і 
найперспективнішою галуззю. Значні площі земельних ресурсів високої якості та сприятливі кліматичні умови визначають високий виробничий та експортний потенціал сільського господарства для міжнародної торгівлі.

Посівні площі сільськогосподарських підприємств України на початок 2019 року складали 27,7 млн га. Під вирощування зернових використовується близько 14,8 млн га, що складає 53\% від загальної посівної площі сільськогосподарських підприємств України на початок 2019 року. Проаналізуємо динаміку посівних площ сільськогосподарських підприємств України за період 1900-2018 роки (Рис. 1).

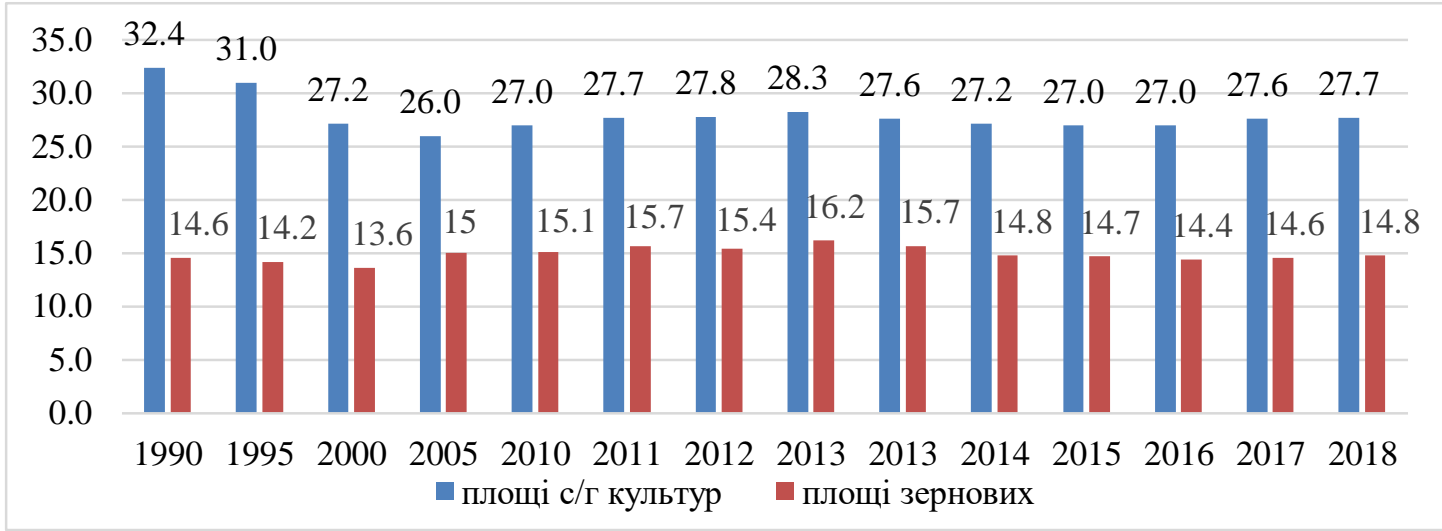

Рис. 1. Динаміка посівних площ українських сільськогосподарських підприємств за 1990-2018 рр., млн га

Джерело: розроблено автором на основі [3].

Період 1990-2000 рр. характеризується значним зменшенням посівних площ, при незначному зменшенні площ зернових. Період 2005-2013 pp. характеризується зростанням посівних площ сільськогосподарських та зернових культур до максимальних значень 28,3 млн га та 16,2 млн га. За період 2013-2016 рр. обидва показники зменшувались до мінімальних значень за цей період 27,0 млн га та 14,4 млн га. У 2017 році спостерігалось їх зростання: посівні площі зросли до 27,6 млн га, а площі зернових до 14,6 млн га. У 2018 році зросли площі зернових культур до 14,8 млн га. Такі зміни посівних площ залежать від зміни структури попиту на зернові на світовому ринку.

Виробництво зернових в Україні має нестійку тенденцію зміни через вплив багатьох зовнішніх і внутрішніх факторів (Рис. 2).

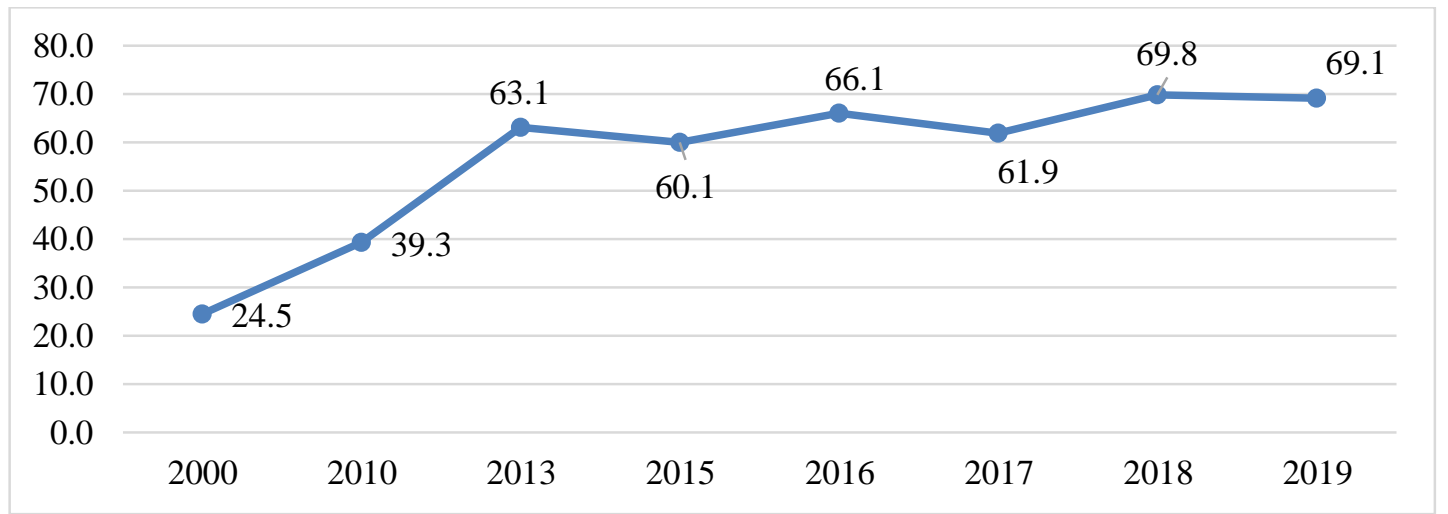
мЛн ТОНн

Рис. 2. Динаміка виробництва зернових культур в Україні за період 2000-2019 pp.,

Джерело: розроблено автором на основі [4].

Отже, за період 2000-2013 роки спостерігається зростання виробництва зернових 
культур від 24,5 млн тонн до 63,1 млн тонн. Починаючи з 2013 року до 2019 року спостерігається нестійка тенденція зміни виробництва зернових культур в межах від 60,1 млн тонн до 69,8 млн тонн. Зокрема, у 2018 році виробництво зернових досягло найбільшого значення за цей період - 69,8 млн. тонн, а у 2019 році - знову знизилось до значення 69,1 млн. тонн.

Проаналізуємо місце України серед країн-виробників зерна. Виробництво зернових культур в цілому у світі та у розрізі країн-лідерів представлено у таблиці 1.

Таблиця 1

Величина і структура світового виробництва

зернових культур за країнами за 2017-2019 роки

\begin{tabular}{|l|c|c|c|c|}
\hline \multirow{2}{*}{ Країни світу } & \multicolumn{2}{|c|}{$2017 / 2018$ м. p. } & \multicolumn{2}{c|}{$2018 / 2019$ м. p. } \\
\cline { 2 - 4 } & млн тонн & $\%$ & млн тонн & 20,8 \\
\hline Китай & 550,0 & 21,0 & 545,3 & 16,7 \\
\hline США & 437,4 & 16,7 & 438,3 & 9,9 \\
\hline Індія & 258,2 & 9,9 & 258,9 & 4,1 \\
\hline РФ & 127,5 & 4,9 & 107,4 & 4,5 \\
\hline Бразилія & 97,5 & 3,7 & 117,0 & $\mathbf{2 , 7}$ \\
\hline Україна & $\mathbf{6 1 , 1}$ & $\mathbf{2 , 3}$ & $\mathbf{6 9 , 6}$ & 3,0 \\
\hline Аргентина & 58,7 & 2,2 & 78,9 & 2,2 \\
\hline Канада & 56,2 & 2,1 & 58,0 & 1,9 \\
\hline Індонезія & 48,9 & 1,9 & 49,7 & 1,5 \\
\hline Пакистан & 40,4 & 1,5 & 39,1 & 1,4 \\
\hline Мексика & 36,9 & 1,4 & 35,7 & 1,3 \\
\hline Туреччина & 33,8 & 1,3 & 33,3 & 1,1 \\
\hline Австралія & 33,6 & 1,3 & 28,3 & 1,0 \\
\hline Таїланд & 25,6 & 1,0 & 25,9 & 28,2 \\
\hline Інші країни & 751,0 & 28,7 & 740,0 & 100,0 \\
\hline Всього & 2616,8 & 100,0 & 2625,4 & \\
\hline
\end{tabular}

Джерело: розроблено автором на основі [5].

Світове виробництво зерна в 2017/2018 маркетингових роках становило 2616,8 млн тонн, а у 2018/2019 маркетингових роках - 2625,4 млн тонн. Отже, у персональному заліку найбільшу частку у структурі світового виробництва зерна за останні два маркетингові роки займає Китай $(21,0 \%$ та 20,8\%), другу за величиною - США (16,7\%), третю - Індія (9,9\%), решта країн мають менше 9\% у загальній структурі світового виробництва зерна, причому Україна має 2,3\% та 2,7\% (шосте і сьоме місце серед світових виробників зернових культур).

В Україні виробництво зернових культур приблизно на 97\% формується за рахунок таких трьох основних культур як: пшениця, кукурудза, ячмінь, Причому, у 2019 році кукурудза становила $42 \%$ виробництва зернових культур, пшениця - $41 \%$, ячмінь $14 \%$, та $3 \%$ - решта [2].

Проаналізуємо позиції України на світовому зерновому ринку як виробника зернових за чотири останні маркетингові роки у таблиці 2.

Таблиця 2

Виробництво зернових культур у світі та Україні (за основними видами) за 20152019 роки, млн тонн

\begin{tabular}{|l|c|c|c|c|c|c|c|c|}
\hline \multirow{2}{*}{ Вид зернових } & \multicolumn{2}{|c|}{$2015 / 2016$ м. p. } & \multicolumn{2}{|c|}{$2016 / 2017$ м. p. } & \multicolumn{2}{c|}{$2017 / 2018$ м. p. } & \multicolumn{2}{|c|}{$2018 / 2019$ м. p. } \\
\cline { 2 - 10 } & Світ & Україна & Світ & Україна & Світ & Україна & Світ & Україна \\
\hline Пшениця & 738,1 & 27,3 & 756,3 & 26,8 & 762,6 & 27,0 & 731,5 & 25,1 \\
\hline Кукурудза & 1015,1 & 23,3 & 1127,8 & 28,0 & 1080,1 & 24,1 & 1123,7 & 35,8 \\
\hline Ячмінь & 149,5 & 8,8 & 147,0 & 9,9 & 143,1 & 8,7 & 138,8 & 7,6 \\
\hline Всього & 1902,7 & 59,4 & 2031,1 & 64,7 & 1985,8 & 59,8 & 1994 & 68,5 \\
\hline
\end{tabular}

Джерело: розроблено автором на основі [6].

Виробництво зернових культур у світі та Україні змінювалось стрибкоподібно за 
цей період. У світі виробництво зернових культур коливалось у межах від 1902,7 млн тонн у 2015/2016 м. р. до 1994 млн тонн у 2018/2019 м. р. В Україні виробництво зернових культур коливалось у межах від 59,4 млн тонн у 2015/2016 м. р. до 68,5 млн тонн у 2018/2019 м. р. Отже, у світі найбільше вироблялось кукурудзи, потім пшениці і найменше ячменю, причому така тенденція спостерігалась у всі роки досліджуваного періоду. Що стосується України, то тут не прослідковується така стійка тенденція, однак перше і друге місце з виробництва зернових розділяли пшениця і кукурудза. Найменше вироблялось ячменю у всі роки досліджуваного періоду [6].

Проаналізуємо зміну частки виробництва зернових культур України у світовому виробництві зернових культур на рисунку 3.

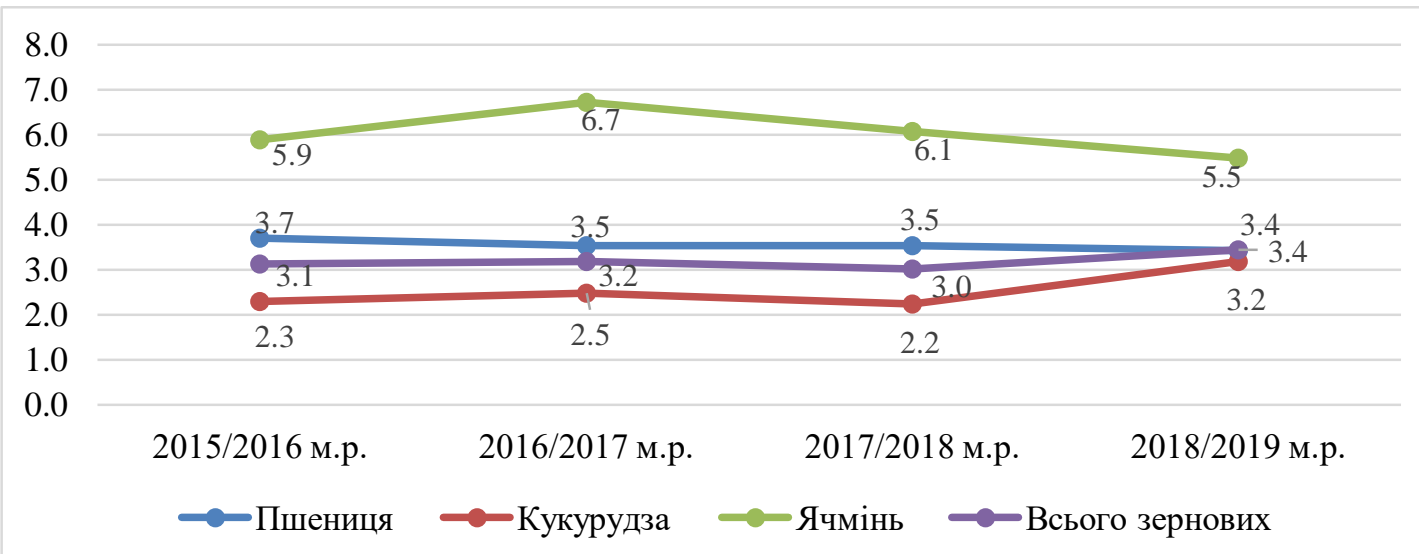

Рис. 3. Динаміка частки виробництва зернових України у світовому виробництві зернових в цілому та за їх видами за 2015-2019 рр., \%

Джерело: розроблено автором на основі [6].

Спостерігаємо незначне коливання частки виробництва зернових культур України у світовому виробництві зернових культур. Так, частка України у виробництві зернових коливалась від 3,0\% у 2017/2018 м. р. до 3,1\% у 2015/2016 м. р., до 3,2\% у $2016 / 2017$ м. р. та до 3,4 у 2018/2019 маркетингових роках. Тобто, Україна займає помітне місце на світовому зерновому ринку як виробник, і за останній рік ії позиції дещо посилились. Спостерігається майже подібна тенденція зміни частки вироблених зернових культур в Україні до світового виробництва зернових в цілому та за їх видами. Найвищі відносні показники виробництва за різними видами зернових культур і в цілому у світі та Україні були досягнуті у різні роки досліджуваного періоду.

Отже, як показують результати аналізу, Україна достойно представлена на світовому ринку зернових культур як важливий виробник даного виду сільськогосподарської продукції. Разом з тим, Україна є важливим світовим експортером зернових. Обсяг експорту основних зернових культур України за 2015-2019 рр. відображений у таблиці 3.

Таблиця 3

Експорт основних зернових культур у світі та Україні за 2015-2019 рр., млн. тонн

\begin{tabular}{|l|c|c|c|c|c|c|c|c|}
\hline \multirow{2}{*}{ Вид зернових } & \multicolumn{2}{|c|}{$2015 / 2016$ м. p. } & \multicolumn{2}{|c|}{$2016 / 2017$ м. p. } & \multicolumn{2}{c|}{$2017 / 2018$ м. p. } & \multicolumn{2}{c|}{$2018 / 2019$ м. p. } \\
\cline { 2 - 10 } & Світ & Україна & Світ & Україна & Світ & Україна & Світ & Україна \\
\hline Пшениця & 171,7 & 17,4 & 182,4 & 18,1 & 184,0 & 17,8 & 175,4 & 16,0 \\
\hline Кукурудза & 145,2 & 16,6 & 142,3 & 21,3 & 152,8 & 18,0 & 171,9 & 30,3 \\
\hline Ячмінь & 27,6 & 4,7 & 29,6 & 5,3 & 26,9 & 3,2 & 25,6 & 4,4 \\
\hline Всього & 344,5 & 38,7 & 354,3 & 44,7 & 363,7 & 39 & 372,9 & 50,7 \\
\hline
\end{tabular}

Джерело: розроблено автором на основі [7].

Сумарний світовий експорт основних зернових культур зростав 3 кожним роком 
від значення 344,5 млн тонн у 2015/2016 м. р., до 354,3 млн тонн у 2016/2017 м. р., до 363,7 млн тонн у 2017/2018 м. р. та до 372,9 млн тонн у 2018/2019 м. p.

Що стосується України, то експорт основних зернових культур за досліджуваний період змінювався стрибкоподібно. Найменше значення 38,7 млн тонн спостерігалось у 2015/2016 м. р., а найбільше - 50,7 млн тонн у 2018/2019 м. p. [7]

Отже, за період 2015-2019 pр. на світовому ринку зернових найбільше експортували пшеницю, потім кукурудзу, і найменше ячмінь, причому співвідношення між ними залишається приблизно однакове. Що стосується України, то у всі роки досліджуваного періоду, крім 2015/2016 м. р. переважав експорт кукурудзи. Експорт ячменю, порівняно з іншими видами зернових був незначний, до 6 млн тонн.

Проаналізуємо зміну частки експорту основних видів зернових культур України у світовому експорті зернових культур і за їх видами у таблиці 4.

Таблиця 4 Динаміка частки експорту основних зернових культур України в загальному світовому експорті за 2015-2019 pp., \%

\begin{tabular}{|l|c|c|c|c|c|c|c|}
\hline \multirow{2}{*}{$\begin{array}{c}\text { Вид зернових } \\
\text { культур }\end{array}$} & $\begin{array}{c}2015 / \\
2016 \text { м. p. }\end{array}$ & $\begin{array}{c}2016 / \\
2017 \text { м. p. }\end{array}$ & $\begin{array}{c}2017 / \\
2018 \text { м. p. }\end{array}$ & $\begin{array}{c}2018 / \\
2019 \text { м. p. }\end{array}$ & \multicolumn{2}{|c|}{$\begin{array}{c}\text { Абсолютне відхилення до } \\
\text { попереднього року }\end{array}$} \\
\hline Пшениця & 10,1 & 9,9 & 9,7 & 9,1 & $-0,2$ & $-0,2$ & $-0,6$ \\
\hline Кукурудза & 11,4 & 15,0 & 11,8 & 17,6 & 3,5 & $-3,2$ & 5,8 \\
\hline Ячмінь & 17,0 & 17,9 & 11,9 & 17,2 & 0,9 & $-6,0$ & 5,3 \\
\hline Всього & 11,2 & 12,6 & 10,7 & 13,6 & 1,4 & $-1,9$ & 2,9 \\
\hline
\end{tabular}

Джерело: розроблено автором на основі [7].

Частка України в експорті зернових коливалась від 10,7\% у 2017/2018 маркетингових роках до $11,2 \%$ у 2015/2016 м. р., до 12,6\% у 2016/2017 м. р. та досягла найкращого значення 13,6\% світового експорту у 2018/2019 м. р.

Тобто, Україна у всі роки досліджуваного періоду займає значне місце на світовому зерновому ринку не тільки як виробник, а і як експортер зерна, і за останній рік іiі позиції значно покращились (на 3\%). Це відбулося через значне зростання позицій у експорті кукурудзи і ячменю та незначне зменшення позицій у експорті пшениці.

Повній реалізації виробничого і експортного потенціалу українського ринку зерна перешкоджають наступні основні проблеми, які існують на ньому: крайній ступінь нерозвиненості наземної і водної експортної інфраструктури, при якій елеватори і порти переповнені зерном; висока вартість і низька якість зберігання зерна на елеваторах; несталість і досить великі коливання цін на зерно, переважно через нестабільність національної валюти; низька урожайність зернових через застаріле обладнання та техніку, неефективні методи ведення сільського господарства [16, С. 133-134].

Проведені дослідження дозволили окреслити перспективні напрямки підвищення позицій України на світовому ринку зерна: освоєння нових ринків і збільшення частки зернового ринку за рахунок покращення якості зерна і поглиблення його переробки; оптимізація землеволодіння та землекористування; ріст обсягів виробництва зерна та його якості за рахунок залучення іноземних інвестицій для покращення матеріальнотехнічної бази, технологій сільськогосподарського виробництва; подальший розвиток ринкової інфраструктури; раціональне державне регулювання, подолання корупції; досягнення інституційної сталості за рахунок завершення земельної реформи і посилення інтеграційних процесів на внутрішньому ринку $[17,18]$.

Висновки. На основі проведеного дослідження позицій України на світовому ринку зернових культур можна зробити наступні висновки і окреслити перспективи подальших досліджень за даною темою, а саме: 
- обгрунтовано актуальність теми дослідження, сформульовано постановку проблеми, представлено аналіз останніх досліджень вітчизняних науковців, праці яких присвячені аналізу вітчизняного і світового зернового ринку. Окремо виділено питання, які потребують подальшого опрацювання, сформульовано мету статті, викладено основний матеріалів дослідження. Крім того, конкретизовано проблеми, які перешкоджають зростанню позицій України на світовому ринку зерна та подано напрями їх вирішення;

- проведено грунтовний аналіз потенціалу (рис. 1, 2) та позицій України як виробника на світовому ринку зерна (табл. 1, 2; рис. 3). Отож, на початок 2019 року під посівні площі сільськогосподарських підприємств України було виділено 27,7 млн га, а під вирощування зернових 14,8 млн га (53\% від загальної посівної площі вітчизняних аграрних України). За період з 2000 до 2019 року виробництво зернових культур в Україні зросло з 24,5 млн тонн до 69,1 млн тонн. Україна у всі роки досліджуваного періоду займає помітне місце на світовому ринку зерна як виробник, і за останній рік іiі позиції дещо посилились (3,4\% ринку у 2019 році). У розрізі окремих видів зернових культур, найвищі позиції Україна займає за виробництвом ячменю (5,5\% у 2019 році);

- аналіз позицій України як експортера на світовому ринку зерна (табл. 3, 4) показує, що за досліджуваний період частка України в експорті зернових досягла найвищого значення 13,6\% світового експорту у 2018/2019 м. р. Тобто, Україна позиціонує себе як серйозний гравець на світовому зерновому ринку не тільки як виробник, а й як експортер; - окреслено ключові проблеми, які перешкоджають зростанню позицій України на світовому ринку зерна як виробника та як експортера (високий рівень світової конкуренції та проблеми вітчизняної аграрної сфери). Запропоновані основні напрями зростання виробничого та експортного потенціалу України на світовому зерновому ринку (зростання конкурентоспроможності українського зерна та врегулювання вітчизняного ринку зернових).

Сповна використовуючи свій ресурсний потенціал (високий рівень природної родючості грунтів, сприятливі кліматичні умови, дешева робоча сила), долаючи існуючі проблеми на вітчизняному ринку зернових, Україна має високі шанси не тільки зберегти, а й посилити свої позиції як вагомого і успішного гравця на світовому зерновому ринку.

\section{Список бібліографічного опису}

1. Алтухов А. Основа развития зернового рынка - териториально- отраслевое разделение труда. АПК: Экономика, управление: теоретический и научно-практический журнал. 2011. № 11. С. 7-13.

2. Ірина Грузінська, Альона Смагіна, Мануел Айрапетов, Віталій Жигадло Зелена книга «регулювання ринку зерна». URL: http://www.eu4business.eu/files/medias/regulation.gov_ua_regulyuvannya_rinku_zerna.1506350134.pdf.

3. Рослинництво України 2017 http://www.ukrstat.gov.ua/druk/publicat/kat_u/2019/zb/04/zb_rosl_2018.pdf.

$$
\text { 4. Статистичнй } 3 \text { збірник «Сільське }
$$

http://www.ukrstat.gov.ua/druk/publicat/kat_u/publ7_u.htm.

5. United States Department of Agriculture. Foreing Agriculture Service. URL: https://www.fas.usda.gov/data

6. Організація Продовольства і сільського господарства при ОOH. URL: http://www.fao.org/faostat/ru/\#data/QC

7. United States Department of Agriculture Foreign Agricultural Service Grain: World Markets and Trade. URL: https://apps.fas.usda.gov/psdonline/circulars/grain.pdf

8.Збарський В.К., Николюк О.Д. Пріоритети інвестиційної діяльності фермерських господарств. Економіка АПК. 2013. № 5. C. 67-71.

9.Карпенко А.М. Концептуальні засади організації ринку землі сільськогосподарського призначення в Україні. Економіка та управління АПК. 2018. № 2. C. 40-47. URL:http://nbuv.gov.ua/UJRN/ecupapk_2018_2_6

10. Кириленко І.Г., Кравчук В.П. Актуальні проблеми земельного ринку в Україні. Економіка АПК. 2012. № 5. С. 2629.

11. Майстро С.В. Необхідність та напрями удосконалення механізму державного регулювання розвитку ринку земель сільськогосподарського призначення в Україні. Теорія та практика державного управління. 2015. Вип. 2. С. 143-150. URL: http://nbuv.gov.ua/UJRN/Tpdu_2015_2_24.

12. Саблук П.Т., Шпикуляк О.Г. Фінансові проблеми розвитку ринку зерна в Україні. Еконоліка АПК. 2008. № 12. С. 69-75.

13. Саковська О.М. Розвиток та функціонування ринку зерна України. Збірник наукових праць Таврійського державного агротехнологічного університету (економічні науки). 2013. № 2 (6). С. 322-332.

14. Худолій Л.М. Економічний механізм формування та функціонування ринку зерна в Україні: автореф. дис. на здобуття наук. ступеня докт. екон. наук: спец. 08.07.02 «Економіка сільського господарства і АПК». ННЦ «Нститут аграрної економіки» УААН. Київ, 1999. 32 с. 
15. Шпичак О.М., Бондар О.В. Вигоди та проблеми експорту зерна з України. Економіка АПК. 2013. № 10. С. 5.

16. Лебідь В.М., Прищепа К.Є. Сучасний стан ринку зерна України, проблеми та перспективи розвитку. Економічний вісник Донбасу. № 1 (31), 2013. С. 131-135.

17. Дзядикевич О.Я. Стратегічний аналіз підвищення конкурентоспроможності українського зерна на світовому ринку. International Scientific Journal «Internauka». Series: «Economic Sciences». URL: https://www.internauka.com/uploads/public/15254353167351.pdf.

18. Голомша Н.С., Дзядикевич О.Я. Конкурентні переваги продукції зернової галузі на світовому ринку. Економіка АПК. 2017. №11 (277). С. 61-66.

\section{References}

1. Altuxov A. Osnova razvitiya zernovogo rynka - teritorialno-otraslevoe razdelenie truda. APK: Ekonomika, upravlenie: teoreticheskij i nauchno-prakticheskij zhurnal. 2011. № 11. P. 7-13. [in Russian].

2. Iryna Gruzinska, Aliona Smagina, Manuel Ajrapetov, Vitalij Zhygadlo. Zelena knyga «Regulyuvannya rynku zerna». Retrieved from: http://www.eu4business.eu/files/medias/regulation.gov_.ua_regulyuvannya_rinku_zerna.1506350134.pdf. [in Ukrainian].

3. Roslynnycztvo Ukrayiny $2017 . \quad$ Retrieved from: http://www.ukrstat.gov.ua/druk/publicat/kat_u/2019/zb/04/zb_rosl_2018.pdf. [in Ukrainian].

4. Statystychnyj zbirnyk «Silske gospodarstvo Retrieved from: http://www.ukrstat.gov.ua/druk/publicat/kat_u/publ7_u.htm. [in Ukrainian].

5. United States Department of Agriculture. Foreing Agriculture Service. Retrieved from https://www.fas.usda.gov/data. [in English].

6. Organizaciya Prodovolstva i silskogo gospodarstva pry OON. Retrieved from: http://www.fao.org/faostat/ru/\#data/QC. [in English].

7. United States Department of Agriculture Foreign Agricultural Service Grain: World Markets and Trade. Retrieved from: https://apps.fas.usda.gov/psdonline/circulars/grain.pdf. [in English].

8. Zbarskyj V.K., Nykolyuk O.D. Priorytety investycijnoyi diyalnosti fermerskyh gospodarstv. Ekonomika APK. 2013. № 5. P. 67-71. [in Ukrainian].

9. Karpenko A.M. Konceptualni zasady organizaciyi rynku zemli silskogospodarskogo pryznachennya v Ukrayini. Ekonomika ta upravlinnya APK. 2018. № 2. P. 40-47. Retrieved from: http://nbuv.gov.ua/UJRN/ecupapk_2018_2_6 [in Ukrainian].

10. Kyrylenko I.G., Kravchuk V.P. Aktualni problemy zemelnogo rynku v Ukrayini. Ekonomika APK. 2012. № 5. P. 26 -29. [in Ukrainian].

11. Majstro S.V. Neobxidnist ta napryamy udoskonalennya mexanizmu derzhavnogo regulyuvannya rozvytku rynku zemel silskogospodarskogo pryznachennya v Ukrayini. Teoriya ta praktyka derzhavnogo upravlinnya. 2015. Vyp. 2. P. 143-150. Retrieved from: http://nbuv.gov.ua/UJRN/Tpdu_2015_2_24. [in Ukrainian].

12. Sabluk P.T., Shpykulyak O.G. Finansovi problemy rozvytku rynku zerna v Ukrayini. Ekonomika APK. 2008. № 12. P. 69-75. [in Ukrainian].

13. Sakovska O.M. Rozvytok ta funkcionuvannya rynku zerna Ukrayin. Zbirnyk naukovyh pracz Tavrijskogo derzhavnogo agrotexnologichnogo universytetu (ekonomichni nauky). 2013. № 2(6). P. 322-332. [in Ukrainian].

14. Xudolij L.M. Ekonomichnyj mexanizm formuvannya ta funkcionuvannya rynku zerna v Ukrayini: avtoref. dys. na zdobuttya nauk. stupenya dokt. ekon. nauk: specz. 08.07.02 «Ekonomika silskogo gospodarstva i APK». NNCz «Instytut agrarnoyi ekonomiky» UAAN. Kyyiv, 1999. 32 P. [in Ukrainian].

15. Shpychak O.M., Bondar O.V. Vygody ta problemy eksportu zerna z Ukrayiny. Ekonomika APK. 2013. № 10. P. 5. [in Ukrainian].

16. Lebid V.M., Pryshhepa K.Ye. Suchasnyj stan rynku zerna Ukrayiny, problemy ta perspektyvy rozvytku. Ekonomichnyj visnyk Donbasu. № 1 (31), 2013. P. 131-135. [in Ukrainian].

17. Dzyadykevych O.Ya. Strategichnyj analiz pidvyshhennya konkurentospromozhnosti ukrayinskogo zerna na svitovomu rynku. International Scientific Journal «Internauka». Series: «Economic Sciences». Retrieved from: https://www.internauka.com/uploads/public/15254353167351.pdf. [in Ukrainian].

18. Golomsha N.Ye., Dzyadykevych O.Ya. Konkurentni perevagy produkciyi zernovoyi galuzi na svitovomu rynku. Ekonomika APK. 2017. № 11 (277). P. 61-66. [in Ukrainian].

Дата подання публікації 20.09.2020 p. 